\title{
A VÉLEMÉNYNYILVÁNÍTÁS ÉS A GYÜLEKEZÉS SZABADSÁGÁNAK ÁLTALÁNOS VÉDELME FEHÉROROSZORSZÁGBAN
}

\author{
General Protection of Freedom of Speech and Freedom of \\ Assembly in Belarus
}

\section{Nagy Gellért ${ }^{1}$}

\begin{abstract}
Absztrakt: Fehéroroszország egyike azon államoknak, ahol komoly kérdésként merül fel az alapvető emberi jogok és szabadságok védelme, kiváltképp a véleménynyilvánítás és a gyülekezés szabadságának általános biztosítása. Az elmúlt egy év során e két alapjog számos esetben szenvedett sérelmet a vizsgált államban, ugyanakkor fontos észrevenni, hogy a problémák nem újkeletűek, hiszen Fehéroroszország kapcsán már a múltban is komoly aggályok merültek fel a két említett alapjog tekintetében. Az elemzés során előtérbe kerül a véleménynyilvánítás és gyülekezés szabadságának fehéroroszországi általános helyzete, kitérve a belső szabályozásra, nemzetközi egyezményekre, illetve a Fehéroroszországot érintő nemzetközi joggyakorlatra is. A tanulmány, bár az aktuális helyzetet nem lehet teljes mértékben figyelmen kívül hagyni, általánosságában szemlézi a két vizsgált alapvető emberi jog fehéroroszországi érvényesülését.
\end{abstract}

Kulcsszavak: Fehéroroszország, alapvető emberi jogok, véleménynyilvánítás szabadsága, gyülekezés szabadsága, joggyakorlat

Abstract: Belarus is among the countries where the protection of fundamental human rights - especially those of freedom of speech and freedom of assembly - require serious consideration. During the past year, these two fundamental rights were disregarded on multiple occasions by the

1 Nagy Gellért, Sapientia Erdélyi Magyar Tudományegyetem, joghallgató. E-mail cím: nagy.gellert1999@yahoo.com.

ORCID: https://orcid.org/0000-0002-8633-3038

A szerzô további munkásságát lásd a Magyar Tudományos Művek Tára oldalán: https: $/ / \mathrm{m} 2 . \mathrm{mtmt}$. hu $/$ gui2 $/$ ?type $=$ authors\&mode $=$ browse\&sel $=10079784$ 
Belarusian government. However, it is important to note, that these problems are far from new, as serious concerns have previously arisen regarding the disregard Belarus has shown towards the above-mentioned fundamental human rights. In this analysis, I will focus on the general stance towards freedom of speech and freedom of peaceful assembly. I will also include in my analysis the internal legislation of Belarus, international agreements Belarus is a state party, and the international case-law concerning Belarus.

Keywords: Belarus, fundamental human rights, freedom of speech, freedom of assembly, case-law

\section{BEVEZETÉS}

Ahogyan azt az Egyesült Nemzetek Szövetségének (a továbbiakban rövidítve: ENSZ) Emberi Jogi Bizottsága általános megjegyzéseiben kijelentette, mind a szabad véleménynyilvánítás, mind a békés gyülekezés joga elengedhetetlen alappillér egy magát szabadnak és demokratikusnak tekintő államban, és mint ilyen, sarokkövét képezi az emberi jogok tiszteletben tartásának. ${ }^{2}$

A két alapjog ${ }^{3}$ között szoros kapcsolat figyelhető meg, hiszen a békés gyülekezés joga, mintegy magába foglalja a szabad véleménynyilvánítás jogát is, hiszen mint ilyen, a gyülekezés a véleménynyilvánítás egyik formájaként is értelmezhető. A szabad véleménynyilvánítás és a gyülekezés szabadsága egymástól elválaszthatatlan, hiszen a gyülekezések „szinte kivétel nélkül valamely vélemény kifejezésére irányulnak”. ${ }^{4}$ Ahogyan

2 United Nations Human Rights Committee, 2011. 1.; United Nations Human Rights Committee, 2020 1.o.

${ }^{3}$ Fontos kiemelni, hogy az emberi jogok és szabadságok közötti eltérés elsősorban arra utal, hogy míg az emberi jogok állami beavatkozásnak, szabályozásnak köszönhetően érvényesülnek, addig a szabadságok állami beavatkozástól mentesnek kell lenniük. Ugyanakkor, mára már mind az alapjogoka, mind a szabadságokat az alkotmányok alkotmányos alapjogként, az ember „elidegeníthetetlen jogaként” határozzák meg. A témáról bővebben: Varga, 2019. 193-194.o. Továbbá, elkülönítendő egymástól az alapjog és az emberi jog fogalma is. Az alapvető jogok vagy alapjogok alkotmányban rögzített emberi jogok, vagyis ,az emberi jogokat az alkotmányokban az alapvető jogok formájában ismerik el'. Petrétei, 2009. 413-414.o.

${ }^{4}$ Koltay, 2009. 170. o. 
azt az Emberi Jogok Európai Bírósága ${ }^{5}$ joggyakorlatában is leszögezte ${ }^{6}$, a két alapjog kapcsolata olyannyira szoros, hogy bizonyos körülmények fennállása esetén, a véleménynyilvánítás szabadsága és a gyülekezés szabadsága között lex generalis - lex specialis típusú viszony figyelhetô meg, ${ }^{7}$ hiszen ilyen esetekben a tüntetők nem pusztán véleményük szabad kifejezése érdekében cselekednek, hanem azt is szem előtt tartják, hogy véleményüket másokkal együtt, közösen fejezzék ki. Lényegében, a véleménynyilvánítás szabadságának terjedelme határozza meg azt, hogy a gyülekezés során mit és hogyan lehet kifejezni, ugyanakkor ez a hatás mindkét irányba működik, hiszen a gyülekezés korlátozásával a véleménynyilvánítás szabadságát is korlátozzák. $^{8}$

Fehéroroszország egyike azon államoknak, amelyekkel szemben számos olyan eljárás is folyamatban van, amely a vizsgált két alapjog egyazon időben történő megsértésére, jogtalan korlátozására vonatkozik. A 2020-as év második felében, valamint 2021 első hónapjaiban lezajlott események felnagyították a véleménynyilvánítás és a gyülekezés szabadságának aktuális, fehéroroszországi helyzetére vonatkozó problémákat. Az említett események kapcsán számos esetben merült fel, többségében megalapozottan, hogy Fehéroroszország nem tartja tiszteletben a nemzetközi egyezményekben vállaltakat, nem védi megfelelően az emberi jogokat és szabadságokat.

Ugyanakkor, e jogok és szabadságok védtelensége nem újkeletű az adott államban, hiszen az elmúlt évek során számtalan esetben merültek fel aggályok a fehérorosz állami hatóságok, tüntetések megszervezésével kapcsolatos magatartása kapcsán. Tanulmányomban, elsősorban arra kívánok magyarázatot adni, hogy milyen nehézségek merülnek fel a két vizsgált alapjog védelme kacsán Fehéroroszország esetében, illetve, hogy milyen a nemzetközi megítélése a vizsgált alapjogok fehéroroszországi védelmének.

5 Kiemelendő, hogy Fehéroroszország nem részes fele az Emberi Jogok Európai Egyezményének, ily módon az Emberi Jogok Európai Bíróságának joggyakorlata pusztán, mint elméleti tényező mérvadó.

6 17391/06. 2014.

${ }^{7}$ A két vizsgált alapjog közötti ezen viszony megjelenik továbbá az Ezelin v. France, App. No. 11800/85. 1991. ECtHR ügyben is, melyben a Bíróság kimondta, hogy bizonyos körülmények fennállása esetén a két alapjogot nem szükséges elkülönülten vizsgálni, azok egymásra gyakorolt hatásából kifolyólag. (\$ 35.)

${ }^{8}$ Koltay, 2009. 170.o. 
A továbbiakban, a nemzetközi szabályozás rövid ismertetése után, a Fehéroroszországot részes félként érintő esetekből kívánok néhányat, reprezentatív jelleggel elemezni, és ezáltal feltárni a véleménynyilvánítás és a gyülekezés szabadságának fehéroroszországi helyzetét, amely megfelelő alapként szolgál a kialakul helyzet vizsgálatára is.

\section{NEMZETKÖZI SZABÁLYOZÁS}

Az alapvető emberi jogok kapcsán mindenekelőtt az ENSZ égisze alatt elfogadott Polgári és Politikai Jogok Nemzetközi Egyezségokmányára (a továbbiakban: PPJNE) kell hivatkoznunk, amely rendelkezik mind a véleménynyilvánítás, mind a gyülekezés szabadságáról. Az Egyezségokmány 19. cikkének (2) bekezdése kijelenti, hogy mindenkinek joga van a szabad véleménynyilvánításhoz, amely jogot csak abban az esetben lehet korlátozni, ha az adott korlátozásról törvény kifejezetten rendelkezik, és ha a korlátozás elengedhetetlen mások jogainak és jó hírnevének tiszteletben tartása, illetve az állambiztonság, a közrend, a közegészség vagy a közerkölcs védelme érdekében. Ugyanakkor az Egyezségokmány a 21. cikkelyében kitér a gyülekezés szabadságára is, mondván a békés gyülekezés jogát el kell ismerni, és e jog gyakorlását csak a törvényben megállapított olyan korlátozásoknak lehet alávetni, amelyek egy demokratikus társadalomban az állam biztonsága, a közbiztonság, a közrend, illetve a közegészség és közerkölcs, valamint mások jogainak és szabadságának védelme érdekében szükségesek.

A PPJNE kapcsán fontos kiemelnünk, az ENSZ Emberi Jogi Bizottságát (a továbbiakban: EJB vagy Bizottság), amely 18 független szakértőből áll, földrajzi eloszlás figyelembe vételével, évente háromszor ülésezik és amely konszenzus útján határoz. ${ }^{9}$

A véleménynyilvánítás szabadsága magába foglalja a polgárok tájékoztatáshoz való hozzáférésének jogát, valamint az információk szabad elérésének és terjesztésének lehetőségét. Továbbá a vizsgált alapjog tartalma kiterjed a vélemény szabad megfogalmazására és annak terjesztésére, beleértve „a politikai diskurzusokat, valamely polgár saját vagy közügyekhez füzött véleményét, a választási propagandát, a sajtóban történő véleménynyilvánítást, a kultúrát és a művészeti véleménykifejezést, a tanításokat, illetve a vallási beszédeket"10. Megfigyelhetô, hogy a

\footnotetext{
9 Shaw, 2008. 276.o.

${ }^{10}$ United Nations Human Rights Committee, 2011.3.o.
} 
véleménynyilvánítás szabadságának védelme tartalmazza annak aktív és passzív oldalát is - a saját vélemény formálásának jogát és mások véleményének megismerését is. Mind az aktív, mind a passzív oldalnak elengedhetetlen szerepe van a nyílt társadalmi viták kialakulásában és formálásában. ${ }^{11}$

Egyes szerzők szerint ${ }^{12}$ a véleménynyilvánítás szabadságának egyik legfőbb értéke, hogy ezen alapjog kulcsszerepet tölt be az egyes politikai kérdések kapcsán kialakult közvélemény formálásában. Ebből az okból kifolyólag - amint azt a későbbiekben is látni fogjuk - abban az esetben, ha az egyes országok állami intézkedésekkel kívánják korlátozni a véleménynyilvánítás szabadságát, azt csak kötött keretek, meghatározott feltételek mellett tehetik meg. ${ }^{13}$

A gyülekezés szabadsága a polgárok adott céllal történő békés gyülekezését védi. E szabadság még nem teljesen kiforrott formájával már több, mint 800 évvel ezelőtt találkozhatunk, hiszen 1215. június 10-én Angliában aláírásra került a Magna Charta, amely az alapvető emberi jogok és szabadságok első, kezdetleges kinyilatkoztatása, és mint ilyen tartalmaz a gyülekezés szabadságára vonatkozó rendelkezéseket is. ${ }^{14}$

A Gyülekezés Szabadságának Afrikai Irányelvei értelmében, amely lényegében az ENSZ által megfogalmazottak mentén fejlesztette tovább a békés gyülekezés fogalmát, egy tüntetés békésnek tekinthető, ha azt a szervezők békés szándékkal hirdették meg, és ha az összegyưltek általános szándéka is békés. ${ }^{15} \mathrm{~A}$ békés szándékkal történő meghirdetés véleményem szerint kizárja tehát mindazon gyülekezések védelmét, amelynek meghirdetői erőszakra buzdítanak, agresszióra késztetik a leendő jelenlévőket, vagy amely gyülekezések elsődleges célja az izgatás vagy a felbujtás.

A békés gyülekezéshez való jog egy olyan egyéni jog, amely kollektív módon érvényesíthető, ${ }^{16}$ függetlenül a részt vevő személyek kilététől. Békés

\footnotetext{
${ }^{11}$ Howard, 2018. 11., 15.o.

12 Barendt apud. Howard, 2018. 12.o.

13 Számos ilyen példával találkozhattunk a koronavírus járvány ideje alatt, amikor meghatározott keretek között korlátozták az államok a véleménynyilvánítás szabadságát, az álhírek terjedésének visszaszorítása érdekében.

14 Rohde, 2005. 1.o.

15 Addaney, Gyan Nyorko, Bashoff, 2020. 207.o.

16 El kell különítenünk ugyanakkor a kollektív módon érvényesíthető egyéni jogokat, amelyek olyan egyéni jogok, amelyek csak közösségben, más személyekkel együtt
} 
tüntetésen részt vehetnek tehát az adott állam polgárai, idegen állampolgárok, bevándorlók, menedékkérők, vagy hontalanok is. Ugyanakkor a gyülekezés szabadsága kitér úgy a szabadtéri, mind a beltéri és az online térben zajló tüntetésekre, függetlenül attól, hogy azok magán- vagy közterületen zajlanak. ${ }^{17}$

Az Egyezmény rendelkezéseiből kiindulva megfigyelhető, hogy mind a véleménynyilvánítás mind a gyülekezés szabadságának államok általi korlátozása csak meghatározott körülmények fennállása esetén következhet be. E feltételek a következők:

a) bármely korlátozásról a törvénynek kifejezetten kell rendelkeznie;

b) a korlátozásnak jogszerū célt kell szolgálnia;

c) a korlátozás arányos kell legyen az elérni kívánt jogszerű céllal.

Az első követelmény kapcsán, a szakirodalomban kialakult az a nézet, miszerint a korlátozásokról rendelkező törvénynek hozzáférhetőnek és érthetőnek kell lennie a védett felek, a polgárok számára, annak érdekében, hogy a korlátozás ne legyen jogtalannak tekinthetô. ${ }^{18}$

A második követelmény tekintetében az Egyezségokmány taxatíve felsorolja mindazon érdekeket, amelyek védelme jogszerű célnak minősül a véleménynyilvánítás és a gyülekezés szabadságának korlátozása esetében. Ilyen jogszerű cél mások jogainak és szabadságának tiszteletben tartása, az állambiztonság, a közrend, a közbiztonság, a közegészség és a közerkölcs védelme. E második követelmény kapcsán szükséges kiemelni, hogy e jogszerű célok önmagukban is jelenthetik a korlátozás alapját, ugyanakkor előfordulhatnak olyan esetek is, amikor egy időben, több jogszerű cél is a korlátozás alapjául szolgál. ${ }^{19}$

Míg a korlátozások jogszerűségéhez szükséges első két követelmény viszonylag egyértelmű, és teljesítésük könnyedén vizsgálható addig az arányosság megállapítása sok esetben komoly nehézségeket okoz. Az arányosság követelményének vizsgálatakor a következő kérdést kell szem előtt tartanunk: „arányban állt egymással a cél és az elérését szolgáló eszköz?"20 Az államok beavatkozása tehát, annak érdekében, hogy az megfeleljen az arányosság követelményének, oly mértékű kell legyen, hogy

gyakorolhatóak, a kifejezetten kollektív jogoktól, amelyek önmagában a közösséget, mint egészt illetnek meg. Lásd:Varga, 2019. 198.o.

${ }^{17}$ United Nations Human Rights Committee, 2020. 2.o.

18 Alexe, 2020. 1.o.

19 Predescu, Maria Vlădoiu, 2014. 75.o.

${ }^{20}$ Bychawska-Siniarska, 2018. 46.o. 
általa a jogszerú cél elérhetôvé váljon, ugyanakkor ne támasszon aránytalan korlátozásokat a polgárokkal szemben.

A gyülekezés szabadságának államok általi korlátozása kapcsán ugyanakkor szükséges kitérnünk olyan sajátosságokra is, amelyek a véleménynyilvánítás szabadsága vonatkozásában nem állnak fenn.

Egyrészt, a gyülekezés szabadságát lehet a gyülekezés helyének és idejének függvényében is korlátozni. Mindazon esetekben, amikor a hatóságok a gyülekezés, tüntetés helyére vagy időpontjára vonatkozóan írnak elő korlátozásokat, kötelesek megfelelő alternatívát biztosítani a polgárok számára. ${ }^{21}$ Továbbá, az időpontra vonatkozó korlátozások esetében, az állam által felkínált alternatívának optimálisnak kell lennie, olyan, amely nem gátolja meg a tüntetéssel megfogalmazni kívánt üzenet nagyközönséghez történő eljutását. ${ }^{22}$ Véleményem szerint a fent említettek kiterjeszthetőek a tüntetés helyére vonatkozó korlátozásokra is, hiszen nem számít megfelelő alternatívának egy olyan helyszín kijelölése a hatóságok által, amely gátolja a gyülekezés szervezőit az üzenet széles körû terjesztésében, ezáltal a gyülekezés elveszti legfőbb célját. A fentebb vázolt esetek fennállásakor jogtalan korlátozásra kerül sor.

Másrészt, a gyülekezés szabadsága, ahogyan az az Egyezségokmány megfogalmazásából is kiderül, mindössze a békés gyülekezéseket védi, tehát nem kerülnek a rendelkezés védelme alá azok a tüntetések, amelyeket erôszakos szándékkal hirdettek meg.

Továbbá, az előzetes jóváhagyási rendszeren alapuló ${ }^{23}$ törvényi előírások kapcsán fontos leszögezni, hogy a gyülekezések előzetes bejelentése csak e jog érvényesítését és a közérdek védelmét szolgálhatják, valamint nem lehetnek anyagiszempontból túlzóan terhesek a szervezőkre nézve. ${ }^{24}$

A gyülekezés szabadságának e, fentebb vázolt sajátosságait nem szabad figyelmen kívül hagyni amikor Fehéroroszország esetében vizsgáljuk annak védelmét, hiszen egyrészt a korlátozások többsége a tervezett tüntetések, békés demonstrációk helyszínére vonatkoznak, másrészt, Fehéroroszország esetében, az 1997. december 30. nyilvános rendezvények

21 OSCE/ODIHR Venice Commission, 2010. 17.o.

22 African Commissionon Human and Peoples' Rights. 28.o.

23 Előzetes jóváhagyási rendszerről beszéheltünk minden olyan esetben, amikor a gyülekezést megelőzően szükség van annak, valamely állami közhivatalnál történő bejegyzésére, előzetes jóváhagyására annak érdekében, hogy a gyülekezés szabadságának vedelme alá essen.

24 Addaney - Gyan Nyorko - Bashoff, 2020. 208.o. 
lebonyolítására vonatkozó törvény ${ }^{25}$ (a továbbiakban: 1997. évi törvény) 5. cikkének értelmében, fennáll egy előzetes jóváhagyási rendszer, amelynek az előbbiekben felvázolt értékekhez való megfelelése komoly kérdéseket vet fel. Ezen felmerülő kérdésekre kívánok a továbbiakba válaszokat találni.

\section{A VIZSGÁlt ALAPJOGOK VÉDELMÉNEK ÁLTALÁNOS HELYZETE FEHÉROROSZORSZÁGBAN}

Ahogy az a fentebb vázoltakból kiderült, sok esetben a véleménynyilvánítás és a gyülekezés szabadsága szorosan összefügg egymással, és az egyik megsértése automatikusan maga után vonja a másik alapjog sérelmét is. Mondhatni, „a gyülekezési jog gyakorlása sokak számára az egyetlen igazi eszköz szólásszabadságuk hatékony gyakorlására"26.

A fehéroroszországi szabályozás tekintetében mindenekelőtt fontos kiemelni az 1997. évi törvényt, amely a gyülekezések általános szabályozásáról rendelkezik. Amint arra a fentebb írtakban már kitértem, e törvény 5. cikkének értelmében egy előzetes jóváhagyáson alapuló rendszerről beszélhetünk. Az előzetes jóváhagyást a gyülekezés szervezőinek kell kérvényezniük a helyi hatóságoktól, abban az esetben pedig, ha a gyülekezés kettő vagy több területi közigazgatási egységen belül zajlik, vagy a résztvevők tervezett száma meghaladja az ezer föt az adott régió hatóságainak jóváhagyására is szükség van. Az előzetes jóváhagyásra vonatkozó kérvényt legkevesebb 15 nappal a gyülekezés előtt az illetékes hatóságokhoz kell benyújtani. A hatóságok a kérvényt annak helyszínének, időpontjának, a résztvevők tervezett számának, illetve a közbiztonsági és köztisztasági vállalatokkal megkötött szerződéseknek fényében bírálja el. Ugyanakkor, a törvény 6. cikkének értelmében a helyi hatóságok vezetői minden olyan esetben megváltoztathatják a tervezett gyülekezés helyszínét, időpontját, amikor a gyülekezés mások jogait vagy szabadságait sértheti, vagy közrendet veszélyezteti.

Az 1997. évi törvény 9. cikke kitér a gyülekezések helyszínére és időpontjára, kijelentve, hogy a helyi hatóságok kijelölhetik a gyülekezések állandó helyszínét, továbbá tömegrendezvényeket csak reggel 8 és este 10 óra között lehet megszervezni. A fenti szabályozásból kitűnik, hogy a helyi

25 A törvény angol nyelven az alábbi linken érhető el: https://www.rightofassembly.info/assets/downloads/1997 Mass Events Act.pdf

${ }^{26}$ Koltay, 2009. 169-170.o. 
hatóságok önkényesen korlátozhatják a tömegrendezvények, gyülekezések helyszínét, ezáltal korlátozva a gyülekezés szabadságát, így ellehetetlenítve az egészséges társadalmi véleménynyilvánítás egyik alappillérét.

Az elmúlt egy év során még jobban kidomborodtak a véleménynyilvánítás és a gyülekezés szabadságának ezen belső jogi sajátosságai. Nem hagyhatjuk figyelmen kívül a vizsgált szabályozás társadalomra gyakorolt hatását, azt a tényt, hogy a gyülekezések, tüntetések hatalmi eszközökkel történő korlátozása miképp hat a társadalmi, politikai diskurzusokra a vizsgált államban. Számos esetben erőszakos következményekkel járó tett köthető azon tényhez, hogy Fehéroroszország évekig, hatalmi eszközökkel, önkényesen korlátozta az állampolgárok vizsgált alapjogait, fosztotta meg őket a politikai véleményük, nézeteik kinyilatkoztatásától. ${ }^{27}$

Nemzetközi szabályozások tekintetében, az alapjogok védelme kapcsán kiemelendő egyrészt az Európa Tanács égisze alatt elfogadott Emberi Jogok Európai Egyezménye, másrészt az ENSZ Közgyúlése által 1966-ban elfogadott PPJNE. Az Emberi Jogok Európai Egyezségokmányát ugyanakkor Fehéroroszország nem ratifikálta, hiszen nem tagja az Európa Tanácsnak, így esetében nem vizsgálhatjuk sem az Egyezményben vállaltak betartását, sem az abban foglaltak biztosítására létrehozott Emberi Jogok Európai Bíróságának fehéroroszországi gyakorlatát (mivel ilyen nem létezik). A PPJNE kapcsán azonban fontos kitérnünk az EJB gyakorlatára, amelyek keretében az EJB a PPJNE 1966-ban kiadott Kiegészítő Jegyzőkönyve $^{28}$ mentén befogadott megkeresések kapcsán hoz döntést, amely döntések ugyanakkor nem kötelezőek, pusztán ajánlás jellegük van, hiszen az EJB nem bíróság, nincs jogköre az ügyek kötelező megoldására. ${ }^{29}$

Az EJB-hoz benyújtott panaszok közül számos olyan található, amelyekben a vizsgált két alapjog sérelmére egyidőben került sor. E panaszok közül is számottevőek a Fehéroroszország ellenében benyújtottak, így az elkövetkezőkben néhány olyan esetet mutatok, amelyekben a Bizottság megállapította, hogy Fehéroroszország egyszerre sértette meg a megkereséssel élő fél szabad véleménynyilvánításhoz és gyülekezéshez füződő emberi jogait. Ezen esetek valósághű képet nyújtanak a vizsgált alapjogok fehéroroszországi védtelenségének.

27 Bővebben: $\underline{\text { https://freedomhouse.org/country/belarus/freedom-world/2021 }}$ (Kiemelten a D4 és az E1 pontok tekintendőek tanulmányom tárgyához kapcsolódónak) 28 A Kiegészítő Jegyzőkönyvet Fehéroroszország 1992-ben fogadta el magára nézve kötelezőnek. A jegyzőkönyv a UN TreatySeries 171. oldalán érhető el.

${ }^{29}$ Shaw, 2008. 280.o. 


\subsection{Az Anatoly Poplavny és Leonid Sudalenko v. Fehéroroszország eset ${ }^{30}$}

Anatoly Poplavny és Leonid Sudalenko fehérorosz állampolgárok 2010. november 22-én fordultak kérvényükkel a Gomel Városi Végrehajtó Bizottsághoz, amelyben egy általuk tervezett tüntetés jóváhagyását kérték. A megszervezni kívánt tüntetésre december 10-én került volna sor, a város egyik forgalmas, központi terén, ugyanakkor a résztvevők számát kérvényükben a szervezôk legfeljebb ötven főben határozták meg. A tüntetés céljaként a polgárok figyelmének felhívását, tájékoztatását jelölték meg arra vonatkozóan, hogy a közelgö, előrehozott államelnökválasztásokon, az állampolgároknak joguk van távol maradni a szavazástól. ${ }^{31}$ A Végrehajtó Bizottság elutasította a felek kérvényét, mondván abban a felek nem tettek eleget az 1997. évi törvény alapján kiadott 299. számú Végrehajtó Bizottsági rendeletnek, hiszen egyrészt, a felek kérvényükben nem a rendelet által meghatározott helyszínt jelölték meg a tervezett tüntetés színtereként, másrészt kérvényükhöz nem csatolták a rendvédelmi, közegészségügyi és köztisztasági szervekkel megkötött szerződéseik másolatát. ${ }^{32} \mathrm{~A}$ felek, miután a rendelkezésükre álló összes belső jogorvoslati lehetőséget, eredménytelenül, kimerítették, megkeresésükkel az EJB-hoz fordultak.

Poplavny és Sudalenko urak megkeresésükben kifejezték, hogy a hatóságok magatartása és azon tény, hogy kifejezett indoklás nélkül visszautasították a tervezett tüntetés jogszerū megszervezésének jóváhagyását súlyosan sérti a felek PPJNE 19. és 21. cikkelyében foglalt alapjogait. Érvelésükből kitûnik, hogy sem a Végrehajtó Bizottság, sem a nemzeti bíróságok nem indokolták meg a 299. számú rendelet által megállapított korlátozások szükségességét egyetlen jogszerű céllal sem, ennek értelmében tehát a korlátozások nem szolgálták sem az állambiztonság, a közrend, a közbiztonság, a közegészség és a közerkölcs, sem mások jogainak és szabadságainak védelmét. Mindemellett, a felek kijelentették, hogy a nyilvános rendezvényekről szóló törvény rendelkezéseivel a részes állam nem tesz eleget a PPJNE 19. és 21. cikkelyében

\footnotetext{
${ }^{30}$ Communication No. 2139/2012.

${ }^{31}$ Communication No. 2139/2012. 2.1.

32 Communication No. 2139/2012. 2.2.
} 
vállalt kötelezettségeinek, hiszen az említett törvény 6. cikkelye lehetővé teszi, hogy a helyi Végrehajtó Bizottságok diszkrecionálisan korlátozzák a tüntetések, gyülekezések lebonyolításának helyszínét, bármely jogszerű cél megjelölése nélkül. ${ }^{33}$

Az ügy tartalmi kérdései kapcsán a Bizottság leszögezte, hogy a megkereséssel élő felek szerint indokolatlan korlátozásnak számít, bármely jogszerū cél megjelölése nélkül, egy 500.000 fős lakossággal rendelkező városban a tüntetések, gyúlések megszervezésének egyetlen helyszínre történő korlátozása, illetve aránytalan anyagi terhet ró a szervezőkre a kötelező szerződések megkötése a városi közszolgáltató cégekkel. ${ }^{34}$

$\mathrm{Az}$ EJB döntésében kimondta, hogy a szabad véleménynyilvánításhoz és békés gyülekezéshez való jogok, alapköveit kell képezzék bármely demokratikus társadalomnak, és mint ilyenek csak olyan esetekben korlátozhatóak, amikor a korlátozások megfelelnek a szükségesség és az arányosság szigorú feltételeinek. ${ }^{35}$ Ugyanakkor, az EJB megállapítása szerint, sem a Végrehajtó Bizottság, sem egyetlen nemzeti bírósági szerv nem határozott meg olyan jogszerû célt, amely érdekében a gyülekezések helyszínének egyetlen színtérre történő korlátozása megfelelt volna a szükségesség és az arányosság követelményeinek. ${ }^{36}$ Továbbá, minden olyan esetben amikor egy állam korlátozásokat vezet be, annak érdekében, hogy a jogszerú célt összeegyeztethetôvé tegye az egyének jogaival, bármely nemú korlátozás az egyének jogainak érvényesülését kell szem előtt tartsa, a szükségtelen és aránytalan korlátozással szemben. ${ }^{37}$ Mindezek fényében az EJB úgy határozott, hogy a megkereséssel élő felek szabad véleménynyilvánításhoz és békés gyülekezéséhez való jogait jogtalanul korlátozta Fehéroroszország, amely ezáltal megsértette a PPJNE 19. és 21 . cikkelyében foglaltakat. ${ }^{38}$

\footnotetext{
33 Communication No. 2139/2012. 3.1-3.5.

${ }^{34}$ Communication No. 2139/2012. 8.2.

${ }^{35}$ Communication No. 2139/2012. 8.3, 8.5.

${ }^{36}$ Communication No. 2139/2012. 8.6.

${ }^{37}$ Communication No. 2139/2012. 8.5.

38 Communication No. 2139/2012.8.4, 8.6.
} 


\subsection{A Zinaida Shumilina és mások v. Fehéroroszország eset ${ }^{39}$}

Zinaida Shumilina fehérorosz állampolgár, 11 további károsult társával együtt, 2011. február 4-én benyújtotta jóváhagyási kérvényét a Gomel Városi Végrehajtó Bizottsághoz, amelyben a város több pontján tervezett békés tüntetések megszervezésére kért engedély a hatóságoktól. A tervezett tüntetések célja a kérvényezők szabad véleménynyilvánítása a korábbi államelnök-jelöltek és támogatóik politikai üldözésével kapcsolatban. ${ }^{40}$ A Végrehajtó Bizottság február 17-én hozott határozatában betiltotta a tervezett tüntetések megszervezését. ${ }^{41}$ A Bizottság határozatával szemben a kérvényezők éltek az összes rendelkezésre álló belső jogorvoslati lehetőséggel, ugyanakkor mindezt sikertelenül tették, hiszen a nemzeti bíróságok helyben hagyták a határozatot, mondván az nem ütközik egyetlen jogszabály előírásaiba sem. ${ }^{42}$ Mindezek fényében, 2012 februárjában a megkereséssel élők az EJB-hoz fordultak, mondván a részes állam, Fehéroroszország jogtalanul korlátozta őket a szabad véleménynyilvánításhoz és a békés gyülekezéshez füződő jogukban, amellyel megsértette az állam a PPJNE 19. és 21. cikkelyében vállaltakat.

Döntésében az EJB mindenekelőtt kifejezte, hogy a felek kérése befogadható és tárgyalható a Bizottság által, hiszen a felek kimerítették az összes belső jog által kínált jogorvoslati lehetőséget. ${ }^{43}$

Továbbá, határozatában az EJB megemlítette, hogy a kérvényező felek több, a tüntetés színterének szánt helyszínt is megjelöltek, ám ezek mindegyike elutasításra került. A kötelezően kijelölt helyszínre történő korlátozásra vonatkozóan a helyi hatóságok nem adtak megfelelő magyarázatot, nem sorakoztattak fel olyan indokokat, amely a korlátozás jogszerűségét igazolná államvédelmi, közrendi, közegészségügyi vagy közerkölcshöz köthető céllal. A 299. számú Végrehajtó Bizottsági korlátozások jogszerű célját sem a helyi hatóságok, sem a nemzeti bíróságok nem nevezték meg. ${ }^{44}$ Az EJB kiemelte, hogy a gyülekezések egyetlen, viszonylag eldugott színtérre történő korlátozása, egy Gomel nagyságrendű város esetében, bármely jogszerű cél megadása nélkül egyszerre sérti a

\footnotetext{
${ }^{39}$ Communication No. 2142/2012.

${ }^{40}$ Communication No. 2142/2012. 2.1.

${ }^{41}$ Communication No. 2142/2012. 2.2.

42 Communication No. 2142/2012. 2.2, 2.3.

${ }^{43}$ Communication No. 2142/2012. 5.3.

${ }^{44}$ Communication No. 2142/2012. 6.5.
} 
megkereséssel élő felek szabad véleménynyilvánításhoz és békés gyülekezésre vonatkozó jogát. ${ }^{45}$

\subsection{Az Andrei Strizhak v. Fehéroroszország eset ${ }^{46}$}

Andrei Strizhak fehérorosz állampolgár békés gyúlést kívánt szervezni 2012. július 3-án, a Fehérorosz Függetlenségi Nap alkalmából, azon kifejezett céllal, hogy a gyülés által felhívja a közvélemény figyelmét a független szakszervezetek helyzetére, munkásságára. A gyúlés tervezett helyszíne a Rechytsa város központjában található, nyílt, nagy tömegek számára könnyedén elérhető tér volt. ${ }^{47}$ A megkereséssel élő fél, a gyúlés törvényes megszervezése érdekében benyújtotta kérvényét a Gomel régióban található Rechytsa Körzeti Végrehajtó Bizottsághoz. Kérvényében Strizhak úr kitért, az 1997. évi törvényelöírásainak eleget téve, a tervezett gyưlés céljára, természetére, helyszínére, kezdési időpontjára, a résztvevők becsült számára, a befejezés várható időpontjára, illetve a megtett biztonsági intézkedésekre is. ${ }^{48}$

2012. június 27-én a Rechytsa Körzeti Végrehajtó Bizottság elutasította Strizhak úr kérvényét mondván a kérvényező nem tett eleget sem a nyilvános rendezvényekről szóló törvény, sem a Végrehajtó Bizottság 802. számú nyilvános rendezvények megszervezésére vonatkozó rendelete elő́rásainak. ${ }^{49}$

A fentiek alapján, a belső jogorvoslati lehetőségek kimerítése után, Strizhak úr az EJB-hoz fordult, mondván Fehéroroszország jogtalanul korlátozta ôt a véleménynyilvánítás és a gyülekezés szabadságához füződő jogában. A megkereséssel élő fél kiemelte, hogy ügyével kimerítette az összes belső jogorvoslati lehetőséget, így megkeresése az EJB által befogadható..$^{50}$

Érvelésében a megkereséssel élő fél leszögezte, hogy a gyűlés helyszínének korlátozása meggátolta volna, hogy a rendezvény elérje és megszólítsa a nagyközönséget, ezáltal pedig elvesztette volna célját. ${ }^{51}$

\footnotetext{
${ }^{45}$ Communication No. 2142/2012. 6.7.

${ }^{46}$ Communication No. 2260/2013.

47 Communication No. 2260/2013. 2.1.

${ }^{48}$ Communication No. 2260/2013. 2.2.

${ }^{49}$ Communication No. 2260/2013. 2.3.

${ }^{50}$ Communication No. 2260/2013. 2.8.

${ }^{51}$ Communication No. 2260/2013. 3.4.
} 
A megkeresés tartalmára vonatkozóan a Bizottság egyrészt kijelentette, hogy sem a részes állam, sem annak egyetlen bírósági szerve nem vonultatott fel valós okokat, amelyek alapján a megkereséssel élő fél véleménynyilvánításra vonatkozó szabadsága jogosan korlátozható lett volna. Ennek fényében, bár a korlátozások a belső jog értelmében, a nyilvános rendezvényekre vonatkozó törvény alapján, megalapozottak, ám nincsenek összhangban a PPJNE 19. cikkével, mivel a korlátozás nem felel meg sem a szükségesség sem az arányosság követelményének. Továbbá, a Bizottság a gyülekezés szabadságának korlátozására vonatkozóan is hasonló megállapításokat tett, kiemelve, hogy a gyűlések helyszínének egy adott térre való korlátozása sem nem szükséges, sem nem arányos a PPJNE 21. cikkével összhangban. ${ }^{52}$ Összegezve: a Bizottság döntésében kimondta, hogy Fehéroroszország a PPJNE 19. és 21. cikkében foglaltakat is megsértette azzal, hogy Strizhak urat jogtalanul korlátozta az említett cikkekben foglalt alapjogainak gyakorlásában. ${ }^{53}$

Fehéroroszország tehát nem tett eleget az Egyezségokmányból fakadó kötelezettségeinek, hiszen nem garantálta, illetve jogtalanul korlátozta a véleménynyilvánítás- és a gyülekezés szabadságának gyakorlását állampolgárai számára. Amint azt a fent írtakban már említettem, a szabadságoknak mindenféle állami beavatkozástól mentesnek kell lenniük, ${ }^{54}$ azáltal tehát, hogy Fehéroroszország, a meghatározott feltételek be nem tartásával hozott korlátozásokkal beavatkozott a vizsgált alapjogok gyakorlásába megszegte az Egyezségokmányban vállaltakat.

A vizsgált három esetből kitűnik, hogy Fehéroroszország tekintetében nem újkeletû probléma a véleménynyilvánítás és a gyülekezés szabadságának korlátozása, hiszen a nagyszámú megkeresések is jól tükrözik, hogy a PPJNE vállaltak nem épültek be maradéktalanul Fehéroroszország jogrendjébe. Ugyanakkor, a vizsgált jogok sérelme az elmúlt időszakban még inkább szembetűnővé vált, a következőkben ismertetett események fényében.

\footnotetext{
52 Communication No. 2260/2013. 6.3-6.5.

${ }^{53}$ Communication No. 2260/2013. 6.8.

54 Varga, 2019. 193.o.
} 


\section{A VÉLEMÉNYNYILVÁNÍTÁS ÉS A GYÜLEKEZÉS SZABADSÁGA A 2020-AS ESEMÉNYEK TÜKRÉBEN}

2020 augusztusában Alyaksandr Lukashenka megnyerte (immár sorozatban hatodik alkalommal) a fehérorosz államelnök-választásokat, a szavazatok 80,1 százalékával. A választás végkimenetelének tisztaságát kifogásolva, Lukashenka legfőbb kihívójának, Sviatlana Tsikhanouskayának a hívei utcára vonultak élvén gyülekezési és véleménynyilvánítási szabadságukkal. Tsikhanouskaya állítása szerint, az államelnök-választások eredményét megmásították, hiszen a párhuzamos számításai szerint a szavazatok nagyjából 60 százalékát ő kapta. ${ }^{55}$

A választások végkimenetele ellen több városban és több napon át tüntető tömeggel szemben a rendvédelmi szervek kirívó keménységgel léptek fel, sok esetben fizikai erőszak alkalmazását sem megvetve.

Augusztus 9. és 12. között a rendőrök Minszkben és számos más nagyvárosban léptek fel erőszakkal a tüntetők ellen, gumilövedéket, könnygázt és kábító gránátokat használva, csak ebben a négy napban közel 7.000 állampolgárt vettek őrizetbe, akiket később, sokszor embertelen, méltóságot és egészséget sértő körülményeknek kitéve vallattak. ${ }^{56}$ Szeptember folyamán a békés tüntetések, és az ez ellen fellépő rendőri intézkedések folytatódtak. Egyes jelentések szerint november közepéig mintegy 25.000 ezer tüntetőt vettek ôrizetbe, ${ }^{57} 2020$ végéig e szám meghaladta a $32.000 .^{58}$

A fehérorosz állami hatóságok továbbá monitorozták az őrizetbe vett személyek közösségi médiaplatformjait, annak érdekében, hogy a tüntetéseken való részvételüket igazolják, megalapozzák az esetleges súlyosabb büntetéseket. Mindezek mellett, a Synesis magánvállalat is segítséget nyújtott, biztosítva a hatóságok számára olyan arcfelismerô szoftvereket, amelyekkel elősegítették a tüntetéseken résztvevők felismerését és büntetését. ${ }^{59}$ Megfigyelhető, hogy az államelnök-választás eredményével kapcsolatban kicsúcsosodott azon gyakorlat, amelyet Fehéroroszország már ezt megelőzően is előszeretettel alkalmazott, amint azt a fentebb vázolt régebbi jogesetek is tükröznek, éspedig, hogy minden rendelkezésre álló

\footnotetext{
55 BBC News, 2020.

${ }^{56}$ Human Rights Watch, 2020.

${ }^{57}$ Human Rights Watch, 2020.

${ }^{58}$ Freedom House, 2021.

${ }^{59}$ Freedom House, 2021.
} 
eszközzel korlátozzák a gyülekezés és a véleménynyilvánítás szabadságát politikai kérdésekben. Az állami szervek általi, fentebb vázoltakban történő fellépést nem tette indokolttá egyetlen jogszerű cél sem, így nem voltak szükségesek, továbbá a hatóságok fellépései nem feleltek meg az arányosság elvének sem, hiszen az állami szervek oly eszközökkel léptek fel a tüntetők ellen (gumilövedék, könnygáz stb.), amelyek nem voltak indokoltak. Mindezek tükrében, a 2020. év őszén zajlott tüntetések során Fehéroroszország jogtalanul korlátozta polgárait a véleménynyilvánításhoz és a gyülekezéshez fűződő szabadságukban.

Ugyanakkor, a közéleti szereplők és a politikai kérdések pont, hogy megkövetelik az élesebb kritikákat. A politikusok saját elhatározásuk révén kerülnek a közélet „homlokterébe”, így keményebb kritikáknak is ki vannak téve, tehát nem sérelmezhetnek olyan bírálatokat, amelyek átlagember tekintetében nagyobb védelmet indokolnak. ${ }^{60}$ Ennek fényében még inkább indokolatlannak tűnnek a fehérorosz rendvédelmi szervek fellépései, amelyek következtében korlátozták állampolgáraik számára a véleménynyilvánítás és a gyülekezés szabadságát.

\section{KONKLÚZIÓ}

Megfigyelhető, hogy véleménynyilvánítás és a gyülekezés szabadságával kapcsolatos aggályok forrásaként maga Fehéroroszország belső jogi szabályozása szolgál. Az 1997. évi törvény 9. cikkelyének 2. bekezdése értelmében, a helyi hatóságok (elsősorban a Végrehajtó Bizottságok, nyilvános események megszervezésére vonatkozó rendeletei által) kijelölhetik, kizárólagosan meghatározhatják a gyúlések, békés tüntetések helyszíneit. A Végrehajtó Bizottságoknak ezáltal joguk van leszúkíteni a tervezett nyilvános események helyszínét egyetlen színtérre, anélkül, hogy megnevezésre kerülne bármely olyan jogszerű cél, amely az adott korlátozások előírását indokolttá tenné. A gyülekezések helyszíneinek korlátozása, leszúkítése egy olyan lépés, amelyet az államok megfelelő körültekintéssel és a már fentebb vázolt kötött keretek között tehetnek meg. Fehéroroszország esetében, a tüntetések helyszínének önkényes kijelölése nagy mértékben gátat szab a szabad gyülekezésnek és véleménynyilvánításnak, így e korlátozás jelentősen befolyásolja a közéletet, a politikai nézetek kinyilatkoztatását.

${ }^{60}$ Grád, Weller, 2011. 546-547.o. 
A békés gyülekezések ily módon történő korlátozása, amellyel magától értetődő módon a szabad véleménynyilvánítás is korlátozásra kerül, az EJB joggyakorlatának tükrében nem felel meg a szükségesség és arányosság követelményeinek, így maga a fehérorosz belső jogi szabályozás megy szembe a PPJNE előírásaival, amelyek védelmét az aláíró államok, így Fehéroroszország is, vállalt. ${ }^{61}$

Továbbá, a gyülekezések előzetes bejelentésen alapuló rendszere Fehéroroszország esetében nem a védett alapjog, a gyülekezés szabadságának érvényesülését és gyakorlását tartja szem előtt, hanem, mint ahogyan az a fentírtakból is kitűnik, egy olyan „szűrőt” képez, amely nagyrészt ellehetetleníti az egyes nézetek, vélemények kifejezésre juttatását. A fehérorosz bejelentésen alapuló rendszer tehát inkább gátolja, mint védi a békés gyülekezéshez való jog érvényesülését.

Másrészt, nem felel meg a szükségesség és arányosság követelményének azon elő́rás sem, amely a tüntetések, gyűlések szervezőit kötelezi visszterhes szerződések megkötésére olyan intézményekkel, amelyek feladata a közbiztonság és a közegészségügy felügyelete. Úgy vélem, az ezen szolgáltatókkal kötött szerződések kötelezővé tétele aránytalan terhet ró a szervezókre, amelynek következtében, bár közvetetten ugyan, de sérül a személyek szabad véleménynyilvánításhoz és békés gyülekezéshez füződő joga.

Mindezek mellett, a 2020. évi események során olyan állami fellépéssel is találkozhattunk, amely sértette az állampolgárok véleménynyilvánításhoz és békés gyülekezéshez füződő jogát, hiszen ezen fellépések sem nem feleltek meg az arányosság követelményének, sem nem voltak jogszerû célon nyugvóak.

Összességében, kijelenthető, hogy a tanulmányomban vizsgált alapjogok védelme több esetben is súlyosan sérült Fehéroroszországban, nem pusztán a 2020. évi események során, hanem már azt megelőzően is, a jogok aránytalan és szükségszerűtlen korlátozásából kifolyólag, így tehát szükséges a belső szabályozások átgondolása, megreformálása, annak érdekében, hogy az állampolgárok szabadon gyakorolhassák alapvető emberi jogaikat.

61 Bár a fehérorosz törvények értelmében mindazon nemzetközi szerződések előírásai, amelyekhez Fehéroroszország is csatlakozott részét képezik a belső jognak, mégis a gyakorlati alkalmazás során, a fehérorosz jogszolgáltató szervek előnyben részesítik a nemzeti jogszabályokat a nemzetközi szerződésekben vállaltakkal szemben. 


\section{FELHASZNÁLT IRODALOM}

\section{Szakirodalom}

Addaney, Michael. Gyan Nyorko, Michael. Bashoff, Elsabé (2020). Governance, Human Rights and Political Transformation in Africa. Switzerland: Palgrave Macmillan

African Commissionon Human and Peoples' Rights. Guidelines on Freedom of Association and Assembly in Africa. Letöltés helye: https://www.achpr.org/public/Document/file/English/guidelines on freedom of asso ciation_and_assembly_in_africa_eng.pdf (Letöltve: 2021.09.14.)

Alexe, Irina (2020). Libertatea de exprimare, premisă a fericirii.Pandectele Române. 2020/6

Bychawska-Siniarska, Dominika (2018). A véleménynyilvánitás sqabadságának védelme az Emberi Jogok Európai Egyezménye alapján. Strasbourg: Európa Tanács

Grád András, Weller Mónika (2011). A strasbourgi emberi jogi biráskodás kézikönyve. Budapest:HVG-Orac

Howard, Erica(2018). Freedom of expression and Religious Hate Speech in Europe. London/New York: Routlage kiadó

Koltay András (2009). A szólásszabadság alapvonalai. Budapest: Századvég kiadó

OSCE/ODIHR Venice Commission (2010). Guidelines on Freedom of Peaceful Assembly. Letöltés

https://www.osce.org/files/f/documents/4/0/73405.pdf

(Letöltve: 2021.09.14.)

Petrétei József (2009). Az alkotmányos demokrácia alapintézményei. Budapest/Pécs: Dialóg Campus Kiadó

Predescu, Ovidiu. Marian Vlădoiu, Nasty (2014). Drept european și international al drepturilor omului. București: Editura Hamangiu

Rohde F., Stephen (2005). Freedom of Assembly. New York:Factson File Shaw, N. Malcolm (2008). Nemzetközi jog. Budapest: CompLex kiadó United Nations Human Rights Committee(2011). General Comment No. 34 to Art. 19: Freedoms of opinion and expression. Letöltés helye: https://www2.ohchr.org/english/bodies/hrc/docs/gc34.pdf (Letöltés: 2021.09.14) 
United Nations Human Rights Committee(2020). General Comment No. 37 on the right of peaceful assembly. Letöltés helye: https://digitallibrary.un.org/record/3884725 (Letöltés: 2021.09.14.) Varga Attila (2019). Román alkotmányjog. Budapest/Kolozsvár: Forum Iuris Könyvkiadó

\section{Honlapok}

BBC News (2020). Letöltés helye: https://www.bbc.com/news/worldeurope-53780685 (Letöltés: 2021.10.26.)

Freedom House (2021). Letöltés helye: https://freedomhouse.org/country/belarus/freedom-world/2021 (Letöltés: 2021.10.26.)

Human Rights Watch (2020). Letöltéshelye:https://www.hrw.org/worldreport/2021/country-

chapters/belarus? fbclid $=$ IwAR1kSZqGdMpm8g8QcBkCTafYdPP0ZgH NvA7DoLNfQ0 6vMsKIrUH dKx8w\#cba979(Letöltés: 2021.10.26.)

\section{Jogesetek}

Anatoly Poplavny and Leonid Sudalenko v. Belarus, Communication No. 2139/2012. 2012. február 27.-i ítélet.

Andrei Strizhak v. Belarus, Communication No. 2260/2013.2012. november 28.-i ítélet.

Zinaida Shumilina et. al v Belarus, Communication No. 2142/2012. 2012. február 23.-i ítélet.

Case of Primov and other v. Russia, App. No. 17391/06. 2014. október 13.-i ítélet. 